\title{
National Identity Defense In Facing Asean Economic Community Through Curriculum Development
}

\author{
Jagad Aditya Dewantara ${ }^{1)}$, Khabibatul Fatkhi ${ }^{2)}$, Asep Rudi Casmana ${ }^{3)}$ \\ Universitas Tanjungpura, Pontianak, Indonesia ${ }^{1)}$ \\ Universitas Pendidikan Indonesia, Bandung, Indonesia ${ }^{2)}$ \\ Universitas Negeri Jakarta, Jakarta Indonesia ${ }^{3)}$ \\ jagad02@fkip.untan.ac.id
}

\begin{abstract}
Each nation or country has a national identity that is different from another country, so that identity becomes the unique characteristic of a nation. In this era of the 21 st century, the community is demanded to ready to face globalization or ASEAN Economic Community (AEC), which becomes a challenge for Indonesian people in defending nation identity when facing acculturation as a result of the free economy market so many foreigners will come to Indonesia freely. Therefore to solve that problem, it needs an effort to defend the national identity and national identity in facing AEC, so the nation's existence will keep maintained. One of them is through education. This paper aims to find out how to defend national identity through curriculum development that prevailed in Indonesia. The method used in this paper is an analytical description with a literature study that combines systematic review techniques as supporting data. National identity defense can be done through curriculum development in education by presenting or studying national identity in civic education material through the educational syllabus.
\end{abstract}

Keywords: AEC, Nation Identity, Curriculum, Systematic Literature Review

\begin{abstract}
Abstrak. Setiap bangsa atau negara memiliki identitas nasional yang berbeda dari negara lain, sehingga identitas menjadi ciri khas unik suatu bangsa. Di era abad ke-21 ini, masyarakat dituntut siap menghadapi globalisasi atau Masyarakat Ekonomi ASEAN (MEA), yang menjadi tantangan bagi masyarakat Indonesia dalam mempertahankan jati diri bangsa ketika menghadapi akulturasi sebagai akibat pasar ekonomi bebas sehingga banyak orang asing akan datang ke Indonesia dengan bebas. Oleh karena itu untuk mengatasi masalah tersebut, perlu upaya untuk mempertahankan identitas nasional dan identitas nasional dalam menghadapi MEA, sehingga eksistensi bangsa akan tetap terjaga. Salah satunya melalui pendidikan. Makalah ini bertujuan untuk mengetahui bagaimana mempertahankan identitas nasional melalui pengembangan kurikulum yang berlaku di Indonesia. Metode yang digunakan dalam makalah ini adalah deskripsi analitis dengan studi literatur yang menggabungkan teknik tinjauan review sistematis sebagai data pendukung. Pertahanan identitas nasional dapat dilakukan melalui pengembangan kurikulum dalam pendidikan dengan menghadirkan atau mempelajari identitas nasional dalam materi pendidikan kewarganegaraan melalui silabus pendidikan.
\end{abstract}

Kata Kunci: MEA, Identitas Bangsa, Kurikulum, Systematic Literature Review 


\section{INTRODUCTION}

The end of the 20th century and the beginning of the 21 st century is the era of change, which in turn will give impact various life aspects such as economy, education, lifestyle, etc (Carnall, 2001). Nisbet in Aziz and Sapriya (2011) explained that: "All is change". That change also influences life, including society custom. Aziz and Sapriya in their book which is titled The Foundation of Civic Education stated that the change in the 21 st century not only in life aspect but also in the concept of social state or nation-state. The boundaries of states will be difficult to be distinguished depending on viewing it from the social aspect, political aspect, economic aspect or security, and defense aspect (Aziz \& Sapriya, 2011). The world today is facing globalization and liberalization problems and society cannot avoid that condition as explained by Canadian communication experts, McLuhan that in the globalization era, we are not able to leave or escape from global life. 21 st century shows the very significant change toward Knowledge and Technology development which is sophisticated which result in the freedom to catch all information obtained through Knowledge and Technology so now the young generation depends on knowledge and technology.

Aspects of globalization, liberation and society which is later will face ASEAN Economic Community is an aspect which will be faced by society in 21 st century and will be impacted on life style and education of ASEAN Economic Community in which there are many people from abroad (ASEAN countries) who come to Indonesia (Benny \& Abdullah, 2011). One of AEC policy is mutual recognition agreement which stated that there are 7 kinds of job which can enter and exist and free visa policy such as in European Union. In related to it, curriculum should engage and add ways how to strengthened national identity because it is inevitable that with so many people from 9 countries who come to Indonesia, it can result in acculturation which can make Indonesian national identity will be disappeared (Lao-Hakosol \& Walsh, 2016). Therefore, the material is needed for students to make them more understand and recognize Indonesia through national identity. There are many concepts about national identity but civic education curriculum need to be reinforced (Dewantara et al., 2020). There is need of new sub subject matter which is learned in Elementary School, Junior High School, Senior High School and university levels which can reinforce national identity. Even though there are many people from another countries who come to Indonesia, but nation culture is not blended with culture from another countries because citizenship education in Indonesia must be under the ideology of Pancasila (Dewantara et al., 2019).

Based on that problem, the solution is needed for "How to defend Indonesian national identity in the midst of many 
acculturation or with nine countries come to Indonesia which will influence Indonesian national identity. Education field has the role in helping to give solution in facing ASEAN Economic Community.

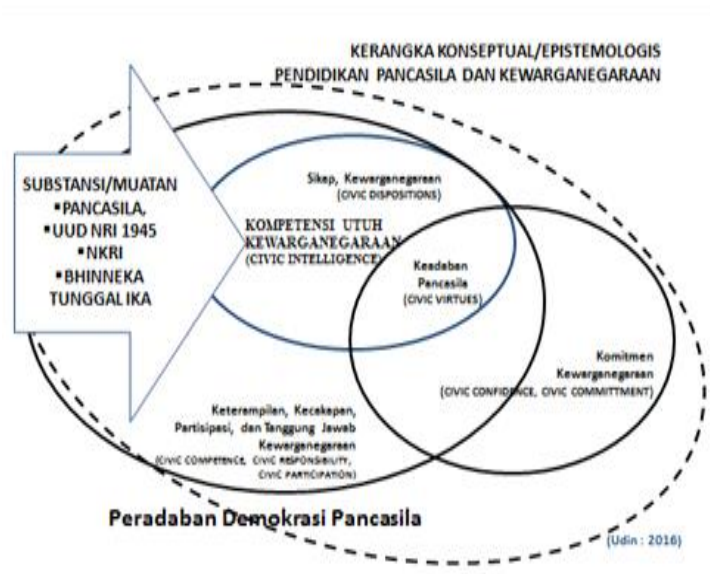

Figure 1. Conceptually/Epistemologis Education's Pancasila and Citizenship (Silabus Pendidikan Kewarganegaraan Tingkat SMA, 2016)

Tabel 1. Syllabus of Class XI about National Security and Defense Material

\begin{tabular}{|c|c|c|}
\hline $\begin{array}{l}\text { Basic } \\
\text { Competence }\end{array}$ & $\begin{array}{l}\text { Learning } \\
\text { Material }\end{array}$ & $\begin{array}{l}\text { Learning } \\
\text { Activity }\end{array}$ \\
\hline $\begin{array}{l}\text { 1. Appreciate } \\
\text { the values } \\
\text { which } \\
\text { arouse } \\
\text { awareness } \\
\text { of the threats } \\
\text { toward } \\
\text { country in } \\
\text { fields of } \\
\text { ideology, } \\
\text { politic, } \\
\text { economic, } \\
\text { social, } \\
\text { culture, } \\
\text { security and } \\
\text { defense and } \\
\text { the } \\
\text { strategies to } \\
\text { overcome it } \\
\text { in building } \\
\text { national } \\
\text { integration }\end{array}$ & $\begin{array}{l}\text { The cases } \\
\text { of threat } \\
\text { toward } \\
\text { ideology, } \\
\text { politic, } \\
\text { economic, } \\
\text { social, } \\
\text { culture, } \\
\text { defense } \\
\text { and } \\
\text { security. } \\
\text { 1. The } \\
\text { threat } \\
\text { toward } \\
\text { national } \\
\text { integrat } \\
\text { ion and } \\
\text { national } \\
\text { identity } \\
\text { defense } \\
\text {. }\end{array}$ & $\begin{array}{l}\text { 1. Observe the } \\
\text { video/film/pic } \\
\text { ture gratefully } \\
\text { or read from } \\
\text { various } \\
\text { sources about } \\
\text { the cases of } \\
\text { threat toward } \\
\text { ideology, } \\
\text { politic, } \\
\text { economic, } \\
\text { social, } \\
\text { culture, } \\
\text { security and } \\
\text { defense. } \\
\text { 2. Identify and } \\
\text { ask the } \\
\text { question by } \\
\text { using high } \\
\text { order thinking } \\
\text { skills (HOTS) } \\
\text { confidently }\end{array}$ \\
\hline
\end{tabular}

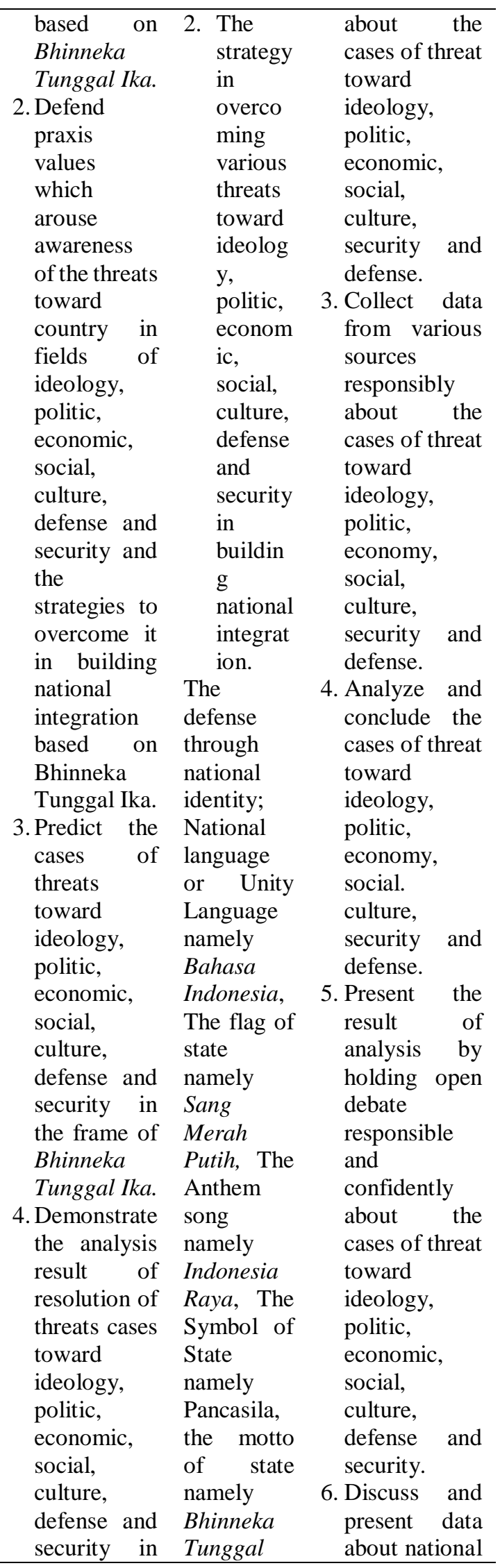




\begin{tabular}{|c|c|c|}
\hline $\begin{array}{l}\text { the frame of } \\
\text { Bhinneka } \\
\text { Tunggal Ika. }\end{array}$ & $\begin{array}{l}\text { Ika, The } \\
\text { Philosophy } \\
\text { Foundation } \\
\text { of State } \\
\text { namely } \\
\text { Pancasila, } \\
\text { The } \\
\text { Constitutio } \\
\mathrm{n} \text { namely } \\
\text { 1945 } \\
\text { Constitutio } \\
\mathrm{n} \text { of The } \\
\text { Republic } \\
\text { of } \\
\text { Indonesia , } \\
\text { The } \\
\text { Conceptio } \\
\mathrm{n} \\
\text { Archipelag } \\
\text { o } \\
\text { Principles, } \\
\text { The local } \\
\text { cultures } \\
\text { which had } \\
\text { been } \\
\text { accepted as } \\
\text { National } \\
\text { Culture. }\end{array}$ & $\begin{array}{l}\text { identity as } \\
\text { threat defense } \\
\text { toward } \\
\text { ideology, } \\
\text { politic, } \\
\text { economic, } \\
\text { social, } \\
\text { culture, } \\
\text { security and } \\
\text { defense. } \\
\text { 7. Analyze } \\
\text { national } \\
\text { identity } \\
\text { defense of } \\
\text { threats toward } \\
\text { ideology, } \\
\text { social, } \\
\text { economic and } \\
\text { national } \\
\text { security. }\end{array}$ \\
\hline
\end{tabular}

Source: Syllabus of Civic Education, Education and Culture Ministry

\section{RESEARCH METHODS}

This paper is arranged by literature study and descriptive-analysis method which is initially analyze and search the literature about national identity. The focus of study is to describe the problem faced in 21 st century which is one of them is about ASEAN Economic Community. The next stage is search the literature by identifying and analyzing the problem and confirming it based on relevant book, journal, and magazine so data can be integrated and analyzed descriptively to obtain the findings related to problem taken by author. In this study, using a systematic literature review (Kamaruddin \& Boon, 2020). The selected research literature was taken from 2012 to 2019, which was downloaded from Taylor and Francis, Science Direct, Google Scholar, SAGE, the Indonesian National Journal, and the Web of Science, the Ministry of Education and Culture, and the Client's books. Most of the articles and literature come from several journals on social science competence, for example, Education journals, Teacher Education Journals, Pendagogik Journals, and periodicals on Indonesian national security. In this paper, researchers integrate and between the online journal literature, books, and syllabus 20122019 as a database in the data search platform on Google Scholar. Based on the search results, most of the papers and research in this study show dimensions related to the AEC and Its Influence Toward Culture \& Education issues, Indonesian Nation Identity Defense in Facing the ASEAN Economic Community, and Curriculum Development in Indonesia. Then in the initial stages, data search found a total of 150 papers and literature related to AEC, Education, Nation Identity, and Curriculum in Indonesia. Later in the second stage, the amount of research found was reduced to a total of 15 for download and referenced this study: (1) the selected literature was limited to issues from 2012 to 2019 to get the most recent reviews of reviews on the National Identity Defense in Facing ASEAN Economic Community Through Curriculum 
Development, (2) The study is related to the challenges of the Indonesian people when facing the AEC era.

\section{DISCUSSION}

\section{AEC and Its Influence Toward Culture \&}

\section{Education}

AEC is pattern of ASEAN economic integration which is formed based on four pillars (Irwan, 2010). First, ASEAN can be made to become central of production and single market. Second, economic region which is competitive. Third, balanced economic growth and integrated into global economy. Based on AEC pillar of 2015, the limitation of professional workforce will be eliminated. This can give opportunity for foreign workforce to enter work field in Indonesia. The big numbers of foreign workforce entering Indonesia will effected on different culture friction so it can result in the muddle in understanding culture and acculturation, so it can undermine the culture. Nation culture will gradually eroded by globalization current through AEC. According to H.A.R.TILAAR (2007: 170): the cultural values of a society or nation which had been held and become a life guidance for a long time cannot be crashed for each other. It means that if these cultural values are differ from the existing values, then that incoming values cannot be made to become a guidance as cultural values in larger community (Tilaar, 2007).
AEC has positive and negative impact toward Indonesian nation particularly in culture. According to Media Indonesia on Thursday March 27, 2014, that the existence of free product and service market will make easier for foreign workers to enter and work in Indonesia which result in competition in employment, besides free product and service market is very influential to culture that is acculturation so community are not able to differentiate which Indonesian culture is and which another nation culture is. Nation culture is national identity or used to be called Indonesian nation identity and it need to be fostered. According to H.A.R. Tilaar (2007; 32), nation identity fostering can be done through formal and informal path. As for fostering in formal path can be implemented through education. National education give big effect on nation identity creation. Ki Hajar Dewantara in H.A.A..R explained that Indonesian culture is culture capstone from each tribes. The culture capstone is local culture element which capable to strengthened national solidarity (Tilaar, 2007).

\section{Indonesian Nation Identity Defense in Facing ASEAN Economic Community}

Each nation in a country has national identity which is different from another country. In globalization era, each nation will show its strength and identity. National identity is identity possessed by a nation and view of life of a nation . Philosophically, 
national identity is unique characteristic of a nation and that identity differentiate that nation from another nation.

National identity has four elements, namely: First, tribes: classes who are descriptive which is similar with category of age and sex. Indonesia has many tribes and ethnics. Second, Religion: Indonesian people is well-known by its community who are religious and believe in God. The religions which are grow and developed in Indonesia are Islam, Christian, Catholic, Hindu, Budha and Confucian. Third, Culture: human knowledge which is used as reference and guidance of conduct (in the form of cultural goods) in accord with environment they face. Forth, Language: Language is a symbol which is arbitrarily form human words which are used as interaction tool among human (Aziz, 2014; Faturay et al., 2017).

Based on 1945 Constitution in article 35-36 C, national identity which shows Indonesian identity among other are:

1. National language or Unity Language namely Bahasa Indonesia.

2. Flag of state namely Sang Merah Putih.

3. The anthem song namely Indonesia Raya.

4. Symbol of state namely Garuda Pancasila.

5. Motto of state namely Bhinneka Tunggal Ika.

6. Philosophy foundation of state namely Pancasila.

7. Constitution (Basic Law) namely 1945 Constitution of The Republic of Indonesia.
8. The form of United State of Republic Indonesia with people sovereignty.

9. Conception of Archipelago Principles.

10.Local cultures which had been accepted as National Culture.

National identity which is explained in 1945 Constitution of Republic of Indonesia Article 35-36 $\mathrm{C}$ is unique characteristic of Indonesian nation and not possessed by another country should be defended. Indonesian people which had been faced by ASEAN Economic Community will result in acculturation so it is difficult for Indonesian people to differentiate their own nation culture from culture of another nation. National identity is defended through education. National identity defense can be done through formal tract (education) and informal tract through family, community, etc.

\section{Curriculum Development in Defending National Identity}

The effort to defend national identity in facing globalization current and ASEAN Economic Community should be implemented through education in each all level of education which is consist of primary education, secondary education and higher education (Qazi \& Shah, 2019). As for national identity defense through education tract can be done through education curriculum (Qazi, 2020) . Act No.20 Year of 2003 about National Education System in article 1 explained that curriculum is set of 
plan and regulation about content, aim and learning material and the way used as a guide to implement learning activity to achieve certain education.

Indonesian nation and state is believed still able to defend the existence and identity of its nation against the threat, obstacle, and disturbance which are come from inside and outside the country because of its people love their homeland and their conviction of the truth of Pancasila as ideology foundation, 1945 Constitution of Republic as constitutional foundation of political system and government and patriotic spirit in proclamation and determination to defend and secure the development in achieving national ideal (Suryanto, 2016). Therefore, development of curriculum based on ideology, Pancasila and 1945 Constitution is very important in defending national identity (Palar \& Rasiah, 2019; Sirozi, 2004).

Curriculum development needs to be done by refer to educational national standard with the principle which is verified in accord with education unit, the local potency and students. Taba in Wiles and Bondi defined curriculum as follow, that "the curriculum is all student learning which are planned and directed by school to attain its educational goals (Taba, 1962, page.11). Curriculum development has correlation with national identity defense that is through civic education, in accord with Act of National Education System, article 37 which explain that curriculum of elementary school, secondary school and higher education should contain civic education. This shows that the role of civic education is very important particularly in national identity defense through material or teaching material. Curriculum development should use appropriate procedure. Taba (1962, page 12) in Wiles and Bondi explained that there are 7 (seven) main elements in steps of curriculum development, namely (Wiles \& Bondi, 2011):

1. Diagnosis of needs

2. Formulation of objectives

3. Selection of content

4. Organization of content

5. Selection of learning experiences

6. Organization of learning experiences

7. Determination of what to evaluate and means of doing.

Fundamental component in learning and curriculum is syllabus (Dewantara \& Sulistyarini, 2020). Curriculum development as national identity defense should be contained in syllabus which means that syllabus of nation security and defense should contain national identity which cannot be omitted or left by Indonesian people. Civic education syllabus should contain 10 (ten) national identity based in 1945 Constitution article 35-36 C. According to Budimansyah dan Suryadi (2008, page 11), function of civic education among other are (Budimansyah, 2016): 
1. First, conservation education, namely developing and sustaining the noble values of Pancasila.

2. Second, social and moral development, namely developing and guiding students to be aware of their rights and responsibilities, obedient to prevailing rules, and has good manner,

3. Third, socio-civic development function, namely developing students in order to understand and become aware of their relationship with others members of the family, school, and society, and in the national-state life.

Encep explained in his journal that curriculum can help restructuration of character and national identity (Nurdin, 2015). Furthermore, Rohayani in her study result corroborated that "school has strategic role in value education; on the other side, the reality shows that they cannot be able to do it alone. Contribution in civic education teaching and learning process is very significant directly and indirectly toward youth's character by 19\% (Rohayani, 2010).

\section{Civic Education as Nation Identity Reinforcement}

Citizenship education focuses on the natural relations of the state and citizens. In this global era, citizenship education is opposed to encouraging citizens to be loyal to national identity (Osler, 2011). Civic education in Indonesia is one form of application of Pancasila values in which the position of Pancasila as nation philosophy and national identity and also as soul to develop civic education in each education level (Elementary School, Secondary School, and Higher Education). Civic education is nation character education whose values are taken from Pancasila so Civic Education is more as a cultural plural reality approach. Muchtar in his book which titled Philosophy of Law: Toward Reinforcing Law System Thinking of Pancasila, explained that civic education as Pancasila education which is functioned as nation intelligence should be made to become capital and asset of educational socio cultural (Gelar, 2014).

The noble values whose truth is believed by Indonesia people and these values are implied in Pancasila principle which is made to become Indonesia nation view of life. According to Jagad and Sugara (2016) that "....for the realization of national defense, the realization of noble values of Pancasila whose truth is believed contain in archipelago principles. Therefore, national identity is not separated from archipelago principles. The nation culture which is very important and should be inherited by nation generation through education is Pancasila which is made to become foundation, view of life and nation philosophy (Jagad \& Sugara, 2016).Nation and state will lose its culture if it is not inherited and defended by nation generation. Education level which is started from 
elementary school until higher education has very important role in defending and developing values of Pancasila in nation and state life (Triyatno, 2012).

\section{CONCLUSION}

Curriculum development through civic education material capable to solve the problem and negative impact of AEC by developing and incorporating nation identity which should be defended by Indonesian nation which comprise: National Language or Unity Language namely Bahasa Indonesia, The flag of state namely Sang Merah Putih, The anthem song namely Indonesia Raya, The symbol of state namely Garuda Pancasila, The Motto of state namely Bhinneka Tunggal Ika, The Philosophy of state namely Pancasila, The constitution (Basic Law) namely 1945 Constitution, The form of United State of Republic of Indonesia with people sovereignty, Conception of Archipelago Principles, Local culture which had been accepted as National Culture. Therefore, Indonesian nation identity will not disappear because of AEC existence and globalization current.

\section{REFERENCES}

[1] Aziz, A. L. (2014). Penguatan identitas bahasa Indonesia sebagai lambang identitas nasional dan bahasa persatuan jelang penerapan Masyarakat Ekonomi ASEAN (MEA) 2015. Studi Sosial, 6(1), 14-20.

[2] Aziz, \& Sapriya. (2011). Teori dan Landasan Pendidikan Kewarganegaraan. Bandung:
Alfabeta.

[3] Benny, G., \& Abdullah, K. (2011). Indonesian Perceptions and Attitudes toward the ASEAN Community. Journal of Current Southeast Asian Affairs, 30(1), 39-67. https://doi.org/10.1177/18681034110300010 2

[4] Budimansyah, D. (2016). Teori Sosial dan Kewarganegaraan. Bandung: Widya Aksara Pers.

[5] Carnall, C. (2001). Global Change: The Impact of Asia in the 21st Century. Journal of Change Management, 2(1), 92-92. https://doi.org/10.1080/714042491

[6] Dewantara, J. A., Efriani, Sulistyarini, \& Prasetiyo, W. H. (2020). Optimization of Character Education Through Community Participation Around The School Environment ( Case Study in Lab School Junior High School Bandung ). Jurnal Etika Demokrasi, 5(1), 53-66.

[7] Dewantara, J. A., Suhendar, I. F., Rosyid, R., \& Atmaja, T. S. (2019). Pancasila as Ideology and Characteristics Civic Education in Indonesia. International Journal for Educational and Vocational Studies, 1(5), 400-405.

[8] Faturay, F., Lenzen, M., \& Nugraha, K. (2017). A new sub-national multi-region input-output database for Indonesia. Economic Systems Research, 29(2), 234-251. https://doi.org/10.1080/09535314.2017.1304 361

[10] Gelar, M. M. B. (2014). Filsafat Hukum: Kearah Memperkuat Pemikiran Sistem Hukum Pancasila. Bandung: Gelar Pustaka Mandiri.

[11] Irwan, A. (2010). Konstruksi dan Reproduksi Kebudayaan. Yogyakarta: Pustaka Pelajar.

[12] Jagad, \& Sugara. (2016). Ideologi Pancasia sebagai Karakter Pendidikan Kewarganegaraan. Bandung: Prosiding Internasional AP3Kni.

[13] Kamaruddin, Z., \& Boon, Y. (2020). Challenges in integrating new teacher development program in schools: A systematic literature review. Universal Journal of Educational Research, 8(5 A), 8188.

https://doi.org/10.13189/ujer.2020.081912

[14] Lao-Hakosol, W., \& Walsh, J. (2016). 
Sustainable Growth Strategies for 999 in the Era of the ASEAN Economic Community: Medical Equipment and Supplies Trading in Thailand during Changing Environmental Conditions. South Asian Journal of Business and Management Cases, 5(2), 136-144. https://doi.org/10.1177/2277977916665918

[15] Nurdin, E. S. (2015). The Policies on Civic Education in Developing National Character in Indonesia. International Education Studies, $8(8)$, 199-209. https://doi.org/10.5539/ies.v8n8p199

[16] Osler, A. (2011). Teacher interpretations of citizenship education: National identity, cosmopolitan ideals, and political realities. Journal of Curriculum Studies, 43(1), 1-24. https://doi.org/10.1080/00220272.2010.5032 45

[17] Palar, M. R. A., \& Rasiah, R. (2019). Universalization of Indonesian cultural and scientific regulations. African Journal of Science, Technology, Innovation and Development, 11(7), 873-882. https://doi.org/10.1080/20421338.2019.1588 510

[18] Qazi, M. H. (2020). Exploring links between national education and students' militaristic national identity constructions-a case study of Pakistani state schools in Islamabad. Journal of Curriculum Studies, 00(00), 1-17. https://doi.org/10.1080/00220272.2020.1755 997

[19] Qazi, M. H., \& Shah, S. (2019). A study of Bangladesh's secondary school curriculum textbooks in students' national identity construction in an overseas context. Asia Pacific Journal of Education, 39(4), 501-516. https://doi.org/10.1080/02188791.2019.1671 806

[20] Rohayani, I. (2010). Pengaruh Proses pembelajaran Pendidikan Kewarganegaraan dan Peniddikan Interventif terhadap Karakter Warga Negara Muda. Jurnal Acta, 4(1), 1-16.

[21] Silabus Pendidikan Kewarganegaraan tingkat SMA. (2016). Kementrian Pendidikan dan Kebudayaan.

[22] Sirozi, M. (2004). Secular-religious debates on the Indonesian National Education System: colonial legacy and a search for national identity in education. Intercultural Education, 15(2), 123-137. https://doi.org/10.1080/14675980420002249
98

[23] Suryanto, S. (2016). Konsep Sistem Pertahanan Nonmiliter: Suatu Sistem Pertahanan Komplemen Sistem Pertahanan Militer dalam Pertahanan Rakyat Semesta. Jakarta: Yayasan Pustaka Obor Indoensia.

[24] Tilaar, H. A. R. (2007). Mengindonesiakan Etnisitas dan Identitas Bangsa Indonesia: Tinjauan dari Perspektif Ilmu Pendidikan. Jakarta: Rineka Cipta.

[25] Triyatno. (2012). Integrasi Nilai-Nilai Pancasila ke dalam Mata Pelajaran Pendidikan Kewarganegaraan sebagai Wahanan Pendidikan Moral bagi Peserta Didik (Studi kasus di Kabupaten Karanganyar Jawa Tengah). Prosiding Semnas LPP Universitas Negeri Surakarta. Surakarta.

[26] Wiles, \& Bondi. (2011). Curriculum Development a Guide To Practice (8th ed.). North Florida: Pearson. 